\title{
choer
}

\section{Os Direitos Humanos como primado de um sentido holístico de Educação para o Desenvolvimento em Contexto de Multiculturalidade}

\author{
Filipe Silvino de Pina Zau \\ Doutor em Ciências da Educação pela Universidade Aberta de \\ Lisboa - Portugal \\ Reitor da Universidade Independente de Angola \\ filipezau@gmail.com \\ https://orcid.org/0000-0002-6520-7614
}

\begin{abstract}
Resumo
A história e as culturas africanas não são conhecidas pelos antigos países colonizadores europeus, nem pelos países que têm uma elevada taxa de afrodescendentes na sua população, devido ao tráfico negreiro, que, no Brasil, terminou com a "Lei Eusébio de Queirós", de 4 de Fevereiro de 1850. Actualmente, o papel socioeconómico e cultural dos negros no desenvolvimento das antigas sociedades escravocratas, não é relatado nas historiografias oficiais desses países e permanece o discurso da "raça", como justificação da escravatura e do próprio tráfico de escravos. A globalização fez crescer as desigualdades que existiam entre os países ricos e os países pobres, assim como as desigualdades no interior de cada sociedade, com uma elevada perda de valores necessários ao primado da paz, da democracia, do Estado de direito, da justiça social e dos direitos humanos. As novas gerações terão de ser formadas, no contexto de um sentido amplo de educação para a solidariedade e para o desenvolvimento, que torne possível o progresso económico e o bem-estar social, a partir do respeito ao direito de ser diferente em cada sociedade.
\end{abstract}

Palavras-chave direitos humanos; multiculturalismo; sentido holístico de educação para o desenvolvimento; bem-estar social.

Conhecer: debate entre o público e o privado 2021, Vol. 11, no 26

ISSN 2238-0426

DOI https://doi.org/10.32335/2238-0426.2021.11.26.4649

Licença Creative Commons Atribuição (CC BY 4.0)

Data de submissão 02 nov 2020

Data de publicação 08 jan 2021 


\title{
Human rights as prime of a holistic sense of development education in a context of multiculturality
}

\begin{abstract}
African history and cultures are not known to the former European colonizing countries, nor to the countries that have a high rate of African descent in their population, due to the slave trade, which in Brazil ended with the "Eusébio de Queirós Law" of February 4, 1850. At present, the socioeconomic and cultural role of black men in the development of former slave societies is not reported in the official historiographies of these countries and the discourse of "race" remains as a justification of slavery and for the slave trade itself.

Globalization has increased the inequalities that already existed between rich and poor countries, as well as inequalities within each society, with a high loss of values necessary for the primacy of peace, democracy, the rule of law, social justice and human rights. The new generations will have to be formed in the context of a broad sense of education for solidarity and development that makes economic progress and social welfare possible, with respect for the right to be different in each society.
\end{abstract}

Key words human rights; multiculturalism; holistic sense of development education; social welfare.

\section{Los derechos humanos como primacía de un sentido holístico de educación para el desarrollo en un contexto multicultural}

\section{Resumen}

La historia y las culturas africanas no son conocidas por los países ex colonizadores europeos, ni por los países que tienen una alta tasa de afrodescendientes en su población, debido a la trata de esclavos, que en Brasil terminó con la "Ley Eusébio de Queirós", de 4 de febrero de 1850. Actualmente, el papel socioeconómico y cultural de los negros en el desarrollo de las antiguas sociedades esclavistas no se reporta en las historiografías oficiales de estos países y permanece el discurso de la "raza", como justificación de la esclavitud y la propia trata de esclavos. La globalización ha aumentado las desigualdades que existían entre países ricos y pobres, así como las desigualdades dentro de cada sociedad, con una alta pérdida de valores necesarios para la primacía de la paz, la democracia, el estado de derecho, la justicia social. y derechos humanos. Las nuevas generaciones deberán ser formadas, en el contexto de un sentido amplio de educación para la solidaridad y el desarrollo, que posibilite el progreso económico y el bienestar social, basado en el respeto al derecho a ser diferente en cada sociedad.

Palabras clave derechos humanos; multiculturalismo; sentido holístico de la educación para el desarrollo; bienestar social. 


\title{
Les droits de l'homme comme primauté d'un sens holistique de l'éducation pour le développement dans un contexte multiculturel
}

\begin{abstract}
Résumé
L'histoire et les cultures africaines ne sont pas connues des anciens pays colonisateurs européens, ni des pays qui ont un taux élevé d'Afro-descendants dans leur population, en raison de la traite négrière, qui au Brésil s'est terminée par la «loi Eusébio de Queirós», de 4 février 1850. Actuellement, le rôle socio-économique et culturel des Noirs dans le développement des anciennes sociétés esclavagistes n'est pas rapporté dans les historiographies officielles de ces pays et le discours de la "race" demeure, comme justification de l'esclavage et de la traite des esclaves elle-même. La mondialisation a accru les inégalités qui existaient entre les pays riches et pauvres, ainsi que les inégalités au sein de chaque société, avec une forte perte des valeurs nécessaires à la primauté de la paix, de la démocratie, de l'état de droit, de la justice sociale et les droits de l'homme. Les nouvelles générations devront être formées, dans le cadre d'un sens large de l'éducation à la solidarité et au développement, qui rend possible le progrès économique et le bien-être social, basé sur le respect du droit à la différence dans chaque société.
\end{abstract}

Mots-clés droits humains; multiculturalisme; sens holistique de l'éducation pour le développement; aide sociale.

\section{Introdução}

África é um continente que se afirma ter sido "descoberto" pelos europeus. Porém, os povos colonizados não se encontravam perdidos, nem necessitavam de nenhum reconhecimento da sua humanidade, nem de nenhuma ratificação da sua identidade.

As independências em África começaram na Líbia (1951), depois no Egipto e no Sudão (1952), mais tarde, em Marrocos e na Tunísia (1956), no Ghana (1957) e na Guiné Conacri (1958). Em 1960, surgem as independências da Nigéria, da Somália, do Gabão, do Senegal, do Mali, da Costa do Marfim, do Benin, do Níger, do Burkina Faso, do Chade, de Madagáscar, da Somália, da Mauritânia, do Togo, dos Camarões, da República Centro Africana, da República do Congo e da República Democrática do Congo (ex-Zaíre).

Posteriormente tornaram-se independentes: a Serra Leoa (1961), a Argélia, o Burundi, o Ruanda e o Uganda (1962); o Malawi, a Zâmbia e a Tanzânia (1964); a Gâmbia e, unilateralmente, pela minoria branca, a Rodésia do Sul, hoje, Zimbabwe; o Quénia, o Botswana e o Lesotho (1966); a Swazilândia, as Ilhas Maurícias, a Guiné Equatorial (1968) e Marrocos, em 1969.

Em 1973, a Guiné-Bissau, foi o primeiro País Africano de Língua Oficial Portuguesa (PALOP) a tornar-se independente e, em 1975, também Cabo Verde, S. Tomé e Príncipe, Moçambique e Angola, tal como as como as Comores. Podemos constatar, que os PALOP foram dos últimos a adquirir a sua autonomização política. 


\title{
Um olhar externo sobre África e os africanos
}

As abordagens sobre África são normalmente analisadas como um todo e não de forma diferenciada, como se não houvesse no continente africano diferentes países, com diferentes culturas e diferentes idiomas. O filósofo africano Kwame Anthony Appiah, um ghanês, filho de um ex-deputado negro do Ghana e de uma inglesa, chama a atenção para a ideia errada que se tem de África como um todo, como "a single continuum"; ou seja, um continente racialmente negro. Para ele, esta ideia é reducionista e foi desenvolvida pela cultura ocidental no século XIX, sendo depois apropriada pelos pan-africanistas, que usaram um discurso invertido da "raça". (APPIAH, 1992, pp.242-243).

Contesta também a ideia, que considera igualmente reducionista, da existência de uma única arte africana, um outro rótulo desenvolvido no Ocidente e afirma que

\begin{abstract}
"[...] a raça, uma experiência histórica comum ou uma metafísica compartilhada, pressupõe falsidades sérias demais para que as ignoremos: [...] Muitas vezes, quem diz isto - quem nega a realidade biológica das raças ou a verdade literal de nossas ficções nacionais - é tratado pelos nacionalistas e pelos 'adeptos da raça', com se estivesse propondo o genocídio ou a destruição das nações, como se, ao dizer que literalmente não existe uma raça negra, tivesse obliterado todos aqueles, que afirmam ser negros [...]. Sou aplicado o bastante para me sentir atraído pela enunciação da verdade, mesmo que o mundo venha abaixo; e sou animal político o bastante para reconhecer, que há lugares em que a verdade prejudica mais do que ajuda." (Idem, p.243).
\end{abstract}

A ideia de África apresenta também um conjunto de opiniões caracterizadas pelo negativismo. Elikia M'Bokolo, um dos mais destacados intelectuais africanos da actualidade, resumiu-as do seguinte modo:

\footnotetext{
"Desmoronamento do Estado; fragmentação do território (que havia sido construído com muito trabalho pela colonização e que se encontra agora repartido em enclaves bélico-mineiros); vida precária dos indivíduos (com poucas garantias de segurança imediata e futura, isenta dos direitos mais fundamentais); agravamento das clivagens sociais nos diferentes campos político-militares; angustiante estado de pobreza sem fim à vista, onde a capacidade de sobrevivência é levada ao extremo; etnização das relações sociais e das alterações na vida política [...] (M’BOKOLO, 2001, Prefácio, in, GONÇALVES, 2003, p.7).
}

CONHECER: DEBATE ENTRE O PÚBLICO E O PRIVADO. V. 11 № 26/2021.1 
Tudo isto é verdade, mas já não é verdade, que estes aspectos são exclusivos da realidade sociológica africana. Ainda a propósito de opiniões negativas sobre África e o seu futuro, há também quem refira, que diferentes discursos académicos criam mundos de pensamento, nos quais as pessoas concebem a sua própria identidade. Daí que os antropólogos ocidentais e missionários tenham criado distorções, não só em relação aos que vieram de fora, mas também em relação aos próprios africanos, ao procurarem compreendê-los. (JEWSIEWICKI, in, MUNDIMBE, 1988, contra-capa). Gnose significa procurar para conhecer, inquirir, métodos de conhecimento, investigação e chegar ao conhecimento com alguém. Gnose é diferente de doxa ou opinião, pelo que gnose não se deve confundir com episteme, entendida, quer como ciência, quer como uma configuração intelectual geral. ${ }^{1}$

\footnotetext{
"Identidade e alteridade são sempre dadas a outros, assumidas por um Eu ou Nós-sujeito, estruturadas em diferentes opiniões e expressas ou silenciadas de acordo com desejos pessoais face a uma episteme". (MUNDIMBE, op. cit., p.ix)
}

Daí se torne necessário considerar, que as identidades culturais não devem ser concebidas como rígidas e imutáveis, mas processos de identificação que se estabelecem num determinado tempo e espaço, dando origem a uma sucessão de autocriações constantes que, de uns tempos para outros, se configuram. Assim sendo, “(...) é necessário conhecer quem pergunta pela identidade, em que condições, contra quem, com que propósitos e com que resultados." (GONÇALVES, op. cit, p.12).

Muitos dos conflitos de identidade não estão associados a questões de carácter essencialmente cultural, mas, sim, ideológico, que Edgar Morin define como mapas:

\footnotetext{
“[...] ou estão próximos da realidade, quando são receptivas à absorção de novas informações; ou, então, criam sistemas imunológicos, mais ou menos eficazes e aproximam-se dos toscos mapas medievais, que representavam o mundo de forma imaginativa e fantasiosa. (MORIN, cit. in, CARMO, 1997, p.134).
}

1 Valentin Mudimbe nasceu na República Democrática do Congo. É filósofo e professor de literatura na Duke University, no Estado da Carolina do Norte, nos Estados Unidos da América 


\title{
Fundamentação teórica Em redor dos Direitos Humanos
}

Um dos maiores registos de respeito pelos direitos civis e humanos em África está relacionado com Nelson Mandela, ${ }^{2}$ que afirmou:

\begin{abstract}
"Eu lutei contra a dominação branca e lutei contra a dominação negra. Eu tenho prezado pelo ideal de uma sociedade democrática e livre, na qual todas as pessoas possam viver juntas em harmonia e com iguais oportunidades. É um ideal pelo qual eu espero viver e que eu espero alcançar. Mas caso seja necessário, é um ideal pelo qual eu estou pronto para morrer". (in, https://www.ebiografia.com)
\end{abstract}

Também, em uma outra oportunidade, reforçou as razões deste seu posicionamento e simultaneamente consagrou a importância do papel da educação, na obtenção do primado dos direitos humanos:

\begin{abstract}
"Ninguém nasce odiando outra pessoa pela cor da sua pele, pela sua origem ou ainda pela sua religião. Para odiar as pessoas precisam aprender e se podem aprender a odiar, podem ser ensinadas a amar, pois o amor chega mais naturalmente ao coração humano do que o seu oposto. A bondade humana é uma chama que pode ser oculta, jamais extinta”. (in, http://pensador.uol.com.br/ frase/MzYONzkx/).
\end{abstract}

A educação representa a única forma de mudança de atitude nas pessoas, porque o processo sistematizado de transmissão de conhecimentos, hábitos e valores provoca mudanças nas pessoas e estas, por sua vez, tendem a mudar as sociedades.

Também a activista paquistanesa Malala Yousafzai, a pessoa mais nova a ser laureada com um Prémio Nobel, conhecida pela luta que empreende em prol dos direitos das mulheres e pelo acesso destas à educação na sua terra natal, no actual contexto de violência extrema levada a cabo, em todo o mundo, por grupos armados que afirmam actuar em nome de uma dada religião, afirmou: "com armas você mata terroristas; com educação você mata o terrorismo".(https://pratique/obemhoje.com/tag/educacao).

Para além desta razão específica, muitas outras concorrem para a mudança através da promoção da pessoa humana e da sua integração na sociedade. O sociólogo português Hermano Carmo refere que, nos dias de hoje, a abordagem sobre os direitos humanos

2 Nelson Mandela, um dos mais importantes líderes da África Negra, foi o vencedor do Prémio Nobel da Paz em 1993, por se ter dedicado à luta contra o "apartheid" e ter sido preso, julgado e condenado à prisão perpétua, em 1964, tendo sido libertado 26 anos depois de cumprida a pena, por pressão da Comunidade Internacional. 
constitui uma exigência e também um recurso da comunidade internacional: uma exigência, face à necessidade de os sistemas políticos se sentirem na obrigação de adoptarem e respeitarem um quadro axiológico normativo de referência cada vez mais conceptual; e um recurso, face às eventuais resistências internas dos governos, face às reformas que se queiram implementar e que a comunidade internacional, a partir do exterior, as pode legitimar.(CARMO, 2011, pp.114-115).

$\mathrm{Na}$ realidade, os direitos humanos foram formalmente emergindo, na Europa, a partir do Direito Internacional Público, face ao desafio de grupos sociais dominados por grupos dominantes. (GALTUNG, 1994, p.226; cit. in, CARMO, 2011, p.115). Mas, os direitos humanos também se foram impondo com fundamentação religiosa, por toda a parte e em todas as épocas, criando um lastro normativo capaz de permitir as primeiras tentativas de os universalizar. Em prol dos direitos humanos, Galtung considera a existência de uma geração zero, onde a Igreja desafiou a aristocracia; de uma primeira geração, onde a burguesia desafiou a aristocracia; de uma segunda geração, onde os camponeses e trabalhadores industriais desafiaram a burguesia; e de uma terceira geração, onde mulheres, crianças, diversos povos oprimidos e a própria Natureza desafiaram a tecnocracia. De acordo com esta evolução, os direitos humanos se foram afirmando, em três grupos distintos, ainda que indivisíveis e interdependentes:

- Direitos civis e políticos (geração azul): "direito à vida, a um julgamento justo, à privacidade, à liberdade de reunião, de expressão e de religião." (HEGARTY,1999, p.28; cit. in, CARMO,2011, p.116).

- Direitos económicos e sociais (geração vermelha): "direito ao trabalho, ao abrigo, à alimentação, à segurança social e aos cuidados de saúde."

- Direitos de solidariedade (geração verde): "direitos colectivos ou de grupo (...) incluem o direito à autodeterminação, (...) ao desenvolvimento, dos povos indígenas à sua identidade, o direito a um ambiente protegido e à paz."

Contudo, ainda segundo Ângela Hegarty,

"[...] foi o holocausto e o facto de a Alemanha ter sido capaz de cometer atrocidades contra milhões dos seus próprios cidadãos, nos anos 30, com pouca interferência de outras nações, que acabou por empurrar a comunidade internacional para a codificação de regras para proteger os direitos do homem."

Foi assim que surgiu um reforço normativo, que, ao procurar viabilizar os princípios aprovados na Carta das Nações Unidas de 1945, levou à aprovação dos seguintes diplomas:

- A Declaração Universal dos Direitos do Homem (1948), que, nos seus 30 artigos garante um conjunto de direitos civis e políticos (1-21) e reconhece vários direitos económicos, sociais e culturais (22-30). Apesar de bastante vaga nas suas disposições 
constitui uma espécie de Magna Carta do Mundo ou, como foi descrita pelo Papa João Paulo II, "a pedra angolar das Nações Unidas";

- Os Pactos Internacionais para os Direitos Civis e Políticos e sobre os Direitos Económicos, Sociais e Culturais (1966), que procuram clarificar a Declaração Universal;

- A Declaração e Programa de Acção de Viena (1993), que afirma a interdependência dos direitos humanos e o seu igual valor, que consagra diversos direitos colectivos, como os das mulheres e explica diversos modos de os monitorizar. (Idem, p.p.27-30).

\section{Direitos humanos e tráfico negreiro}

Grande parte dos grupos societais dos países africanos subsaarianos esteve sujeito ao tráfico negreiro. Por exemplo, até meados do século XIX, a economia de Angola dependia ainda de um intenso tráfico de escravos, que eram embarcados nos portos de Luanda e Benguela, sobretudo, com destino ao Brasil, donde quase todos os produtos eram importados, incluindo a aguardente, a pólvora, a carne seca e a madeira para as construções. De Portugal, Angola recebia soldados e um considerável número de deportados condenados por delito comum ou por razões de consciência (judeus e adeptos da reforma protestante). Chegados a Angola, estes deportados passavam a dedicar-se à actividade militar, ao comércio e ao tráfico de escravos.

Face à pressão da Inglaterra, um país que, desde meados do século XVIII, deu início à revolução industrial e apesar de o dia 10 de Dezembro de 1836 ser, em Portugal, um marco de referência para os legisladores, no que respeita à abolição do tráfico negreiro, só entre 1845-1848 se começaram a sentir os efeitos da sua aplicação prática. Um tratado angloportuguês de Julho de 1842 estipulou que o tráfico que utilizasse barcos portugueses, seria considerado como acto de pirataria (ALEXANDRE, 1979, p.28). Mas como contrabandeando se ganhava mais, do que quando o comércio de escravos era feito sob cobertura legal, este veio a aumentar consideravelmente, até à primeira metade do século XIX. ${ }^{3}$ Entre 1845-1848, começou a diminuir lentamente, ameaçando, por vezes, conseguir alguma recuperação. Até que, através da Lei brasileira de 4 de Setembro de 1850 (também conhecida por Lei Eusébio de Queirós), a importação de escravos para o Brasil acabou por ser também considerado acto de pirataria.

\footnotetext{
"A partir desta altura o tráfico passava a ser um contrabando perigoso para os traficantes, isto é, para a maioria dos comerciantes e das casas das grandes mestiças das praças de Luanda e de Benguela e para aqueles seus clientes que se atrevessem a correr os riscos de forçar o 'bloqueio' naval” (Ibidem).
}

3 Valentim Alexandre também refere que uma das grandes figuras de Luanda ligada ao tráfico de escravos foi D. Ana Joaquina dos Santos Silva, onde uma réplica do seu palácio se encontra hoje na baixa de Luanda. 
Curiosamente, Eusébio de Queirós Coutinho Matoso da Câmara, magistrado, ministro da Justiça (1848-1852) e autor da lei que, no Brasil, reprimiu o tráfico de escravos, nasceu em São Paulo de Luanda (reino do Ndongo ou reino de Angola), em 1812 e faleceu no Rio de Janeiro, em 7 de Maio de 1868. (BETHELL, 1970, p.340; cit in, PÉLISSIER, 1986, p.87). Quer o seu avô e o seu pai, exerceram ambos os cargos de ouvidor-geral da Comarca de Angola, em Luanda. (in, http://pt.wikipedia.org).

O tráfico negreiro e a exterminação dos índios constituem, sem dúvida alguma, dois dos maiores holocaustos já alguma vez praticados contra a humanidade, uma realidade factual que, as ex-potências coloniais e as sociedades escravocratas por elas criadas preferem silenciar, ignorando, até, na sua historiografia oficial, a contribuição dos negros nos seus respectivos processos de desenvolvimento. Tal se deve a um forte preconceito, criado, sobretudo, no início na segunda metade do século XIX, após o francês Arthur de Gobineau ter publicado o seu intitulado "Ensaio sobre a desigualdade das raças humanas". (GOBINEAU, 1985; cit. in, ANDRADE, 1997, p.58).

Nesse seu trabalho, o conde de Gobineau divide a espécie humana em diferentes "raças" (negra, amarela e branca), cada uma delas com caracteres permanentes que, em sua opinião, seriam transmitidos de forma hereditária. Obviamente, uma teoria desprovida de qualquer cientificidade, mas que servia para justificar o hediondo tráfico negreiro, que tinha sido levado a cabo, de forma oficial, até quase à primeira metade do século XIX. É certo que, bem antes Gobineau, outros intelectuais franceses do século XVIII, tiveram uma postura bem diferente, em relação ao tráfico de escravos. De entre eles, destacam-se: Montesquieu, ${ }^{4}$ Helvétius $^{5}$ e, particularmente, Condorcet, ${ }^{6}$ ao considerar que, entre todas as injustiças, todas as crueldades herdadas do passado, nenhuma se lhe afigurava mais odiosa do que o tráfico de escravos. Em 1781, Condorcet passou a adoptar o pseudónimo de "Schwartz" e a autoproclamar-se "negro", como forma de solidariedade para com os africanos subjugados pela escravatura. Ao participar com Abbé Grégoire,7 no "Clube les

4 Charles Luis de Secondat, Barão de Breda e Montesquieu (1689-1755). Escritor e filósofo francês, ficou célebre pela sua teoria de separação de poderes. Foi fundador do liberalismo político e um dos fundadores da sociologia moderna. In, http://fr.encyclopedia.yahoo.com/articles/ma/ma_2194_p0.html, em 11/05/03

5 Claude Adrien Helvétius (1715-1771), filósofo francês, que considerou o homem como produto do meio e da educação. Para ele não existiam desigualdades inatas: "A educação pode tudo". In, http://fr. Encyclopedia.yahoo.com/ articles/h/h0001051_p0html, em 11/05/03

6 Marie Jean Antoine Nicolas de Gritat, marquês de Condorcet (1743-1794), escritor, polemista, sábio, matemático, político e educador francês. A variedade de domínios que abrangia, a diversidade das suas obras e a sua personalidade, faz de Condorcet uma personalidade inclassificável, sendo ainda hoje objecto de debates. In, http://fr.encyclopedia.yahoo.com/ articles/ni/ni_870p0.html, em 11/05/03

7 Henri Gregoire, vulgo, Abbé Gregoire (1750-1831), foi um lutador dos direitos dos judeus e defensor da abolição da escravatura. Foi também um animador de um estudo nacional de dialectos, afim de assegurar a supremacia definitiva do francês como língua de liberdade e de democracia. In, http://fr.encyclopedia.yahoo.com/articles/g/g0003287_p0.html, em $11 / 05 / 03$ 
amis des noirs", Condorcet lutou pela supressão do tráfico e pela abolição completa da escravatura. (BALDINTER, cit. in. ANDRADE, op. cit., p.58).

Antigamente, os negros morriam em massa no Oceano Atlântico, no decurso do tráfico negreiro. Agora, com maior preocupação pelo respeito aos direitos humanos, morrem em massa nas travessias do Mar Mediterrâneo. ${ }^{8}$

\section{Direitos humanos e preconceito racial}

No que respeita à igualdade entre todo o ser humano, já o Papa Paulo III, na Bula de 21 de Março de 1542, havia proclamado a igualdade entre as "raças" e recomendou, que se realizassem casamentos entre colonizadores e colonizados convertidos, com o propósito de mais facilmente enraizar o cristianismo em novas paragens. Esta convicção manteve-se com Pio V, Urbano VIII, Clemente XI, Bento XIV e Gregório XVI.

Na sua Bula de 20 de Dezembro de 1741, o Papa Bento XIV, chegou a emitir a seguinte mensagem: "verbera aqueles que, em vez de levarem apenas ajuda aos infiéis com espírito de missão, Ihes levaram apenas um colonialismo baseado na exploração económica e no desprezo pela dignidade humana." (APPIAH, op. cit., p.243). Isto porque, já em pleno século XVIII, a Europa ocidental estava totalmente envolvida no desumano tráfico negreiro, onde se ganhavam avultadas somas de dinheiro nas colónias com este tipo hediondo de comércio. Então, o discurso da "raça" surgiu, para os Europeus, como uma justificação "moral" ou uma espécie de descargo de consciência.

Na segunda metade do século XIX, poucos intelectuais portugueses tinham uma imagem abonatória do seu país, face ao desenvolvimento constatado em outras nações europeias e sentiam a necessidade de encontrar razões, que justificassem a miséria, a letargia ou, no dizer do escritor Eça de Queirós, o "indiferencismo", face ao período de riqueza e dinamismo vividos nos séculos XV e XVI, a auto-denominada era dos "descobrimentos". (QUEIRÓS, 1880-1882, p.165, cit. in, BARBEITOS, 2000, 599). Na sua obra «Os Maias», Eça de Queirós chegou a justificar, através de uma das suas personagens, "o enfraquecimento dos portugueses como uma pretensa degenerescência da raça.” (QUEIRÓS, 1888, pp.169170; MATOS, A.C., s/d, pp.571-574; MARTINS, 1960, pp.65-69, cit. in., BARBEITOS; op. cit., 559).

Para além de Eça de Queirós, também o político e jornalista António Enes e o historiador Oliveira Martins se encontravam envolvidos na procura de soluções, que levassem Portugal a aproximar-se do progresso europeu. Nem todos, como Oliveira Martins, defendiam a formação de uma União Ibérica, possivelmente influenciado pela perspectiva do economista Friedrich List e da Escola histórica alemã, que se opunham aos pequenos

8 "Salvar vidas no Mediterrâneo. Parlamento Europeu chumbou quatro resoluções", título do semanário português Expresso, de 30 de Outubro de 2019. 
Estados e defendiam a racionalidade económica dos grandes espaços. Mas, no que dizia respeito à crença da "raça", estes três personagens portugueses estavam inteiramente de acordo.

António Enes atribui a classificação de "megera" para toda a mulher africana e crê, que não há negra, que não seja "hedionda". (ENES, 1913, p.163; cit. in, BARBEITOS, op. cit., p.601). Daí que, quer António Enes, quer Mouzinho de Albuquerque, oficial de cavalaria e governador-geral de Moçambique, considerassem que a única forma eficaz de transmitir a civilização portuguesa aos negros, fosse o trabalho manual, já que o mesmo se tornava necessário para levar os africanos a apreciarem a dignidade do trabalho.(DUFFY, 1959, pp.236-242; SAMUELS, 1972, in, CHILCOTE, pp.58-59; cit. in, BENDER, 1976, p.202).

Oliveira Martins, apesar de defender os africanos contra os maus-tratos dos europeus, procurou provar que os negros "são um typo antropologicamente inferior, não raro próximo do anthropoide e bem pouco digno de homem". Utilizando as suas "provas científicas", censurou o esforço missionário em África e, retoricamente, perguntava,

\footnotetext{
"porque não há-de ensinar-se a Bíblia ao gorila ou ao orango, que nem por não terem falla, deixam de ter ouvidos e hão de entender, quasi tanto como entende o preto, a metaphisica da encarnação do Verbo e o dogma da Trindade." (MARTINS, 1920, p.255).
}

E de forma ainda mais brutal justificava do seguinte modo o seu arreigado preconceito racial:

\footnotetext{
“[...] a precocidade, a mobilidade, a agudeza próprias das crianças não thes faltam; mas essas qualidades infantis não se transformam em faculdades intelectuais superiores (...). Há decerto, e abundam documentos que nos mostram ser o negro um tipo antropologicamente inferior, não raro do antropóide, e bem pouco digno de homem. A transição de um para o outro manifesta-se, como se sabe, em diversos caracteres; o aumento da capacidade da cavidade cerebral, a diminuição inversamente relativa do crânio e da face, a abertura do ângulo facial que dai deriva e a situação do orifício occipital. Em todos estes sinais os negros se encontram colocados entre o homem e o antropóide." (Idem, pp.69-71).
}

Nesta conformidade, tornava-se incompreensível conceder a "liberdade" a essa "criança adulta", que só "pela força" conseguia trabalhar: 
"[o negro] trabalha sim, mas não por hábito, por instinto e com o fito de uma capitalização ilimitada como o europeu. Trabalha sim, mas agrilhoado pela necessidade imediata: e as necessidades do negro são curtas, e satisfaz-se com pouco. Não abandona a liberdade e a ociosidade, para eles felizes condições de vida selvagem, pelo trabalho fixo, ordinário, constante, que é a dura condição da vida civilizada".

Daí que se justificasse a escravidão:

\begin{abstract}
"A escravidão tinha pois um papel positivo e economicamente eficaz, sob o ponto de vista da prosperidade das plantações. Não basta dizer que o trabalho escravo é mais caro e que o preto livre trabalha - factos, aliás, exactos em si - porque é mister acrescentar que o preto livre só trabalha intermitentemente ou excepcionalmente; e que o mais elevado preço do trabalho escravo era compensado pela constância e permanência do funcionar desse instrumento de produção." (Idem, pp.219-220).
\end{abstract}

À época, até um bispo português, nascido no Brasil, D. José Joaquim da Cunha de Azevedo Coutinho (1742-1821), publicou um livro em francês, que defendia o comércio de escravos da costa africana. Segundo João Medina, a publicação de D. José Joaquim da Cunha de Azevedo Coutinho, editada em Londres, terá sido impedida de sair em Portugal, por "não se poder aceitar que um bispo viesse a legitimar a prática do comércio negreiro e justificar a própria escravatura", o que já era diametralmente oposto aos princípios do cristianismo.

"Filho de importantes senhores de engenhos de açúcar na região do Rio de Janeiro fez os seus estudos eclesiásticos em Coimbra, sendo depois nomeado para a Catedral do Rio de Janeiro (1784) e bispo de Pernambuco (1794). Em 1798, edita o livro Analyse sur la Justice du Commerce du Rachat des Esclaves de la Cote d'Afrique, na Imprimerie de Baylis, com 68 páginas. Foi ainda designado bispo de Elvas (1806) pouco antes das invasões francesas. Em 1818 foi nomeado InquisitorMor do Reino até à abolição do Santo Ofício pela Assembleia Constituinte, em 1821. Concorreu e foi eleito deputado às Cortes saídas da revolução liberal de 1820, tendo falecido em 1821 depois de a Constituinte ter dissolvido a Inquisição, que já durava em Portugal desde 1536. (MEDINA; HENRIQUES (1996), p.67). 
Segundo Oliveira Martins, entre meados do século XVIII e princípios do século XIX, só de Angola para o Brasil foram transportados mais de 642 mil escravos, à média, de catorze a quinze mil em cada ano. (MARITNS, op. cit., p.58). Dominava o pensamento de que os negros eram inferiores aos portugueses, logo, não valia a pena "civilizá-los" através da educação. (Idem, p.285; cit. in, BENDER, op. cit., p. 202-203; também MAZULA (1995), pp.69-71).

Se entendermos o racismo como sendo "a valorização generalizada e definitiva de diferenças reais ou imaginárias em proveito do acusador e em detrimento da vítima a fim de justificar uma agressão ou um privilégio", é de se levar em conta, desde a forma mais grotesca até à forma mais subtil, os aspectos aqui apresentados. (MEMMI, 1993, p.72). Na realidade, a civilização ocidental era à época marcadamente preconceituosa, chegando a considerar como inferiores não só os negros, mas também os brancos que, socialmente e/ ou sexualmente, se relacionassem com os negros. Neste contexto, países como a Inglaterra chegaram a classificar a situação do empobrecimento do colono português "na escala zoológica entre o macaco e o negro." (GALVÃO, 1937, p.221). Gerald Bender, por seu turno, também refere, que um historiador inglês do século XVIII advertia que, se fossem admitidos negros na Inglaterra, o resultado seria uma mistura contaminada, "[...] até a nação inteira se assemelhar aos portugueses e moriscos na cor da pele e na baixeza da mente." (JORDAN, 1968, pp.254-255; cit. in, BENDER, op. cit., p.26). O governador de Angola, Norton de Matos, em 1912, talvez influenciado por este tipo de pensamento, temia que a "inferioridade" dos africanos, pudesse diluir ou mesmo arruinar a eficiência da colonização, se a administração portuguesa não pusesse "durante um século pelo menos, os maiores obstáculos à fusão da raça branca com as raças indígenas de Angola [...]", ou sejam, evidentemente, os negros e, provavelmente, os mestiços. (NORTON DE MATOS, 1926, pp.42-43 e p.231; e também, BARREIROS, 1929, p.57; cit. in, BENDER, op. cit., p.27).

Após a publicação de "Casa Grande \& Senzala", em 1932, por Gilberto Freyre, havia quem já se tivesse esquecido, que a população portuguesa havia resultado de um caldeamento de vários elementos étnicos: ibéricos, romanos, visigodos, berberes, árabes... Se considerarmos a chegada dos mouros à Península Ibérica a partir do início do século VIII e a conquista do Algarve, ${ }^{9}$ ao tempo de D. Afonso III, em 1250, os mouros, acompanhados de negros, estiveram fixados no espaço territorial ibérico, pelo menos, durante meio milénio. De facto, África e os negros haviam chegado a Portugal, muito antes de Portugal, já miscigenado, até com a componente negro-africana, ter chegado com a sua "missão civilizadora” a África, ao Brasil e à Índia. "Desceu ao esquecimento a dívida inegável

9 ALGARVE, BREVES NOTAS HISTÓRICAS, A palavra Algarve tem a sua origem etimológica na palavra árabe Al-Galb, que significa - o extremo ocidente - ou seja, faixa ocidental que os muçulmanos possuíam na Península lbérica e que abrangia os campos do Ribatejo, Santarém, Lisboa e Sintra. Só mais tarde, é que veio a circunscrever-se apenas ao sul de Portugal. In, http://atelier.hannover2000.mct.pt/ pr558/algar1.html, em 01/03/03 
da nação da gente portuguesa à força de trabalho e ao sangue dos negros africanos." (TINHORÃO, 1988, p422). É, provavelmente, esta miscigenação portuguesa (ela própria também, em parte, afro-descendente), que começa a chegar ao Brasil ainda antes das grandes levas de escravos arrancados do continente africano para o Novo Mundo, após o marquês de Pombal (também ele descendente de negros), ter decretado, através do Alvará de 19 de Setembro de 1761, a proibição de cativos em Portugal.

\footnotetext{
"Apesar da sua pele branqueada, o marquês de Pombal descendia do arcediago Sebastião de Carvalho e de uma negra conhecida por Mãe Marta que, cinco gerações antes, na primeira metade do século XVII, deram início à sucessão dos Carvalhos, no lugar da Mata Escura, província da Beira. Quando Sebastião José de Carvalho e Melo, o marquês de Pombal, caiu em desgraça política surgiu, em 1781, o soneto anónimo, reproduzido, em 1879, por Fortunato de Almeida: "Torna, torna marquês à Mata Escura/ Solar do quinto avô, o arcediago/ Que da mãe Marta, por seu negro afago/ Em preto fê cair tua ventura. (...)/ Foste tenente rei da nossa Atenas/Inspector do erário que bem pinga/Vice papas nas leis, que injusto ordenas/Amigos, e que tal? Cheira a catinga? / Pois é quem governou por nossas penas/ Um quinto neto da rainha Ginga." (Cf. ALMEIDA, 1879, s/p; cit. in, FERRONHA, 2000, in, MOREIRA; VENÂNCIO; p.98)
}

A chegada dos primeiros escravos negros cativos ao reino português ocorre, em 1441 e a primeira proibição para a sua entrada na metrópole, em 1761. Um reforço do poder real a esta ordem de proibição diz respeito à Provisão de 16 de Junho de 1773:

\footnotetext{
“ [...] em todo o reino no Algarve e em algumas províncias de Portugal existem ainda pessoas [...] que guardam em suas casas escravas, humas mais brancas qelles com nomes de Pretas e Negras, ou Mestiças, e outras verdadeiramente negras para pela reprehensível prática perpetuarem os Captiveiros." (LOPES, s/d, in, http://www.portugal-linha.pt).
}

\section{Direitos humanos e assimilacionismo cultural}

Desde 1921, após o Decreto no 77, do Governador Provincial de Angola, Norton de Matos, publicado pelo Boletim Oficial de Angola, no 5, 1aㅡ série (9 de Dezembro de 1921), passava a ser obrigatório o ensino da língua portuguesa nas missões católicas e protestantes e deixava de ser permitido o ensino das línguas estrangeiras e das próprias línguas africanas. Aparentemente estas últimas, sob o pretexto de poderem vir a prejudicar 
a ordem pública e a liberdade ou a segurança dos cidadãos portugueses e das próprias populações africanas:

"Arto 1; ponto 3: É obrigatório em qualquer missão o ensino da Língua Portuguesa; ponto 4: É vedado o ensino de qualquer língua estrangeira. Artº 2: Não é permitido ensinar nas escolas de missões línguas indígenas. Arto 3: 0 uso de língua indígena só é permitido em linguagem falada na catequese e, como auxiliar, no período do ensino elementar da Língua Portuguesa. Parágrafo 1: É vedado na catequese das missões, nas escolas e em quaisquer relações com indígenas o emprego das línguas indígenas, por escrito ou falada de outras línguas que não seja o português, por meio dos folhetos, jornais, folhas avulsas e quaisquer manuscritos. Parágrafo $2^{\circ}$ : Os livros de ensino religioso não são permitidos noutra língua que não seja o português, podendo ser acompanhado do texto de uma versão paralela

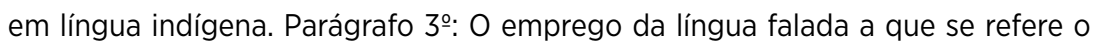
corpo deste artigo e o da versão em língua indígena, nos termos do parágrafo anterior, só são permitidos transitoriamente e enquanto se não generalizar entre os indígenas o conhecimento da Língua Portuguesa, cabendo aos missionários substituir sucessivamente e o mais possível em todas as relações com os indígenas e na catequese as línguas indígenas pela Língua Portuguesa. Artํ 4: As disposições dos dois artigos antecedentes não impedem os trabalhos linguísticos ou quaisquer outras de investigações científicas, reservando-se porém ao governo o direito de proibir a sua circulação quando, mediante inquérito administrativo, se reconhecer que ela pode prejudicar a ordem pública e a liberdade ou a segurança dos 'cidadãos' e das populações indígenas." (BARBOSA, 1969, 139-140)

Entre 1933 e 1961, no regime do Estado Novo, em Portugal, o assimilacionismo cultural, constituía a única forma de promoção social em Angola, na Guiné-Bissau e em Moçambique. Diferentes grupos etnolinguísticos foram sujeitos a um violento processo de "transculturação", para que passassem a adoptar um modelo de vida semelhante ou próximo da vida cultural europeia. Este termo, transculturação, surgem no Dicionário de Etnologia de Michel Panoff e Michel Perrin, ${ }^{10}$ como tendo sido

“[...] criado por volta de 1940 para tentar precisar uma das ideias contidas no termo muito mais geral aculturação e segundo o qual o processo de transição de uma cultura para outra passa por várias fases, desde o declínio ou desaparecimento da cultura tradicional (ou desculturação) até à aquisição à cultura nova (ou endoculturação)". (PANOFF; PERRIN, 1973, 168).

\footnotetext{
10 Este Dicionário de Etnologia também se refere à endoculturação, como a primeira fase do processo de "transmissão da cultura das gerações antigas às gerações mais jovens, dos adultos às crianças", que ocorre numa dada sociedade.
} 
Em 1933, era oficialmente possível a qualquer africano negro ou mestiço ser reconhecido como assimilado (não indígena) e assim atingir o mesmo status legal que um europeu. No entanto, para se habilitar a tal classificação, o indivíduo tinha de ter 18 anos de idade, demonstrar que sabia ler, escrever e falar português fluentemente, ser trabalhador assalariado, comer, vestir e ter a mesma religião que os portugueses, manter um padrão de vida e de costumes semelhante ao estilo de vida europeu e não ter cadastro na polícia. (LEMOS, 1941, pp.49-52; também em MOREIRA, 1955, pp.22-23 e MOREIRA, 1956, p.465).

Em 1952, Angola tinha, apenas 14.898 alunos no ensino primário, onde mais de dois terços eram descendentes de europeus. A título comparativo com outras colónias não portuguesas, o Ghana, de colonização inglesa e com o dobro da população de Angola, tinha, nesse mesmo ano, 418.898 alunos matriculados neste nível de ensino e o ex-Zaire (actual República Democrática do Congo), de colonização belga, três vezes mais populoso que Angola, tinha 943.494 alunos. HARLEY, 1956, p.1258; também SILVA CUNHA, 1953, pp.17-18).

Até 1961, ano em que os angolanos dão início à luta armada em prol da sua independência, a administração colonial portuguesa diferenciava a população de Angola, dividindo-a em "assimilados" (SOUSA FERREIRA, 1974, p. 83-126), o que correspondia a 172 mil brancos, 53 mil mestiços e 30 mil negros, que, correspondiam a menos de $1 \%$ da população total. (BENDER, op. cit., pp.215-220; também em BASTIDE, 1971 ; in, PANOFF ; PERRIN, op. cit., p.64).

Em 11 de Novembro de 1975, Angola, com uma área de $1.246 .700 \mathrm{Km}^{2}$, situada na África Austral, rica em matérias-primas e caracterizada como país multicultural e plurilingue, alcançou a sua independência, após 14 anos de luta armada, já em situação de guerra civil e herdando cerca $85 \%$ de analfabetos. Só, em 2002, consegui alcançar à paz. A guerra, apesar das suas catástrofes e consequências nefastas, ao atingir todos os angolanos, faz parte das vertentes de identidade em Angola, a par da: herança cultural bantu; do contacto de meio milénio com a língua e a cultura portuguesas, de onde resultaram, com o povo português, relações de afectividade e de consanguinidade; e das reivindicações protonacionalistas e associativistas que estão na origem de um nacionalismo moderno africano, que, logo à partida, nasceu faccionado. O maior ou menor grau de melanina não faz parte do conceito de angolanidade.

A este respeito, já antes da independência de Angola, Mário Pinto de Andrade, considerado o decano da sociologia em Angola, havia afirmado:

"A angolanidade requer enraizamento cultural e totalizante das comunidades humanas, abarca e ultrapassa dialecticamente os particularismos das regiões e das etnias em direcção à nação. Esta opõe-se a todas as variantes de oportunismo (com as evidentes implicações políticas) que procuram estabelecer uma correspondência automática entre 
a dose de melanina e a dita autenticidade angolana. Ela é, pelo contrário, linguagem da historicidade de um povo." (KAJIBANGA, 2000, p.94).

\title{
Direitos humanos face aos mitos do luso-tropicalismo
}

Em 1966, o Dr. António de Oliveira Salazar, Presidente do Conselho de Ministros do Estado Novo, o maior responsável pela implantação do regime fascista em Portugal e pela continuação da política colonial em África, após ter aceite as asserções luso-tropicalistas do sociólogo brasileiro Gilberto Freyre, afirmou num discurso considerava que

\footnotetext{
“ [...] a sociedade multirracial é possível, prova-o em primeiro lugar o Brasil, a maior potência latino-americana e precisamente de raiz portuguesa, e seria portanto preciso começar por negar esta realidade, além de muitas outras, para recusar a possibilidade de constituição social deste tipo em território africano." (SALAZAR, 1966; cit. in, BENDER, op. cit.,p.43).
}

Vamireh Chacon, um politólogo brasileiro da Universidade de Brasília e, por sinal, um defensor do chamado "luso-tropicalismo", opõe-se à ideia de que, alguma vez, Gilberto Freyre tenha afirmado que não havia racismo no Brasil, tendo, sobre esta questão, referido o seguinte:

\begin{abstract}
"Não é verdade que Gilberto Freyre tenha declarado o Brasil uma democracia étnica pronta e acabada, quem afirmou a cordialidade brasileira apesar de tantas revoluções e conflitos internos foi, sim, Sérgio Buarque de Holanda que depois andou se explicando sob pressão por Cassiano Ricardo (1948). Gilberto Freyre não apenas se limitou a constatar a tensão racial, menor comparativamente no Brasil que nos Estados Unidos, África do Sul, Europa ou Oriente, também previu que, por isso mesmo, o Brasil pode e deve continuar à frente deste avanço mundial anti-racista." (CHACON, 2000, in, MOREIRA; VENÂNCIO,2000, p.40).
\end{abstract}

Vamireh Chacon referiu também que Gilberto Freyre "não doira a miscigenação brasileira" desde «Casa Grande \& Senzala».

\footnotetext{
“ [...] relações de vencedores com vencidos - sempre perigosas para a moralidade sexual (...); esse período é que sobre o filho da família escravocrata no Brasil agiam influências sociais - a sua condição de senhor cercado de escravos e
} 
animais dóceis - induziu-o à bestialidade e ao sadismo (...); [Violência também contra a mulher], tantas vezes no Brasil vítima inerme do domínio ou abuso do homem".(Cf., FREYRE, 1963, p.461; cit. in, CHACON, op. cit., p.40)

Em 1955, o sociólogo angolano Mário Pinto de Andrade, sob o pseudónimo de Buanga Fele, exprime, com alguma ironia, a sua crítica ao conceito de "luso-tropicalismo":

\footnotetext{
"Na escrita superficialmente brilhante de G. Freyre pode-se portanto ler que o luso-tropicalismo é simultaneamente um conceito, uma teoria e um método de colonização. Poder-se-ia portanto defini-lo como sendo: Uma vocação congénita dos portugueses em serem atraídos pela mulher de cor nas suas relações; o desinteresse dos portugueses pela exploração económica nos trópicos; a manutenção de relações sociais com os habitantes dos países tropicais com vista à criação da mobilidade vertical na vida social e política". (FELE, 1955; cit. in, KAJIBANGA, 1999, p.3).
}

Mário Pinto de Andrade denunciava sobretudo, a ausência de assimilação e integração de valores tropicais na cultura lusitana (ANDRADE, 1958, Prefácio; in, ANDRADE (1958b), cit. in, Kajibanga, op. cit., p.3) e concluía que o luso-tropicalismo "não sendo válido para explicar a formação do Brasil, é inteiramente falso para as circunstâncias coloniais da África." (ANDRADE, 1978, p.253; cit. in, KAJIBANGA, 1999, op. cit., p.3).

Víctor Kajibanga, o sociólogo angolano, ainda sobre esta questão, sustentando-se no martiniquês, teórico da negritude, Aimé Césaire (1913-2008) e no sociólogo e político angolano Mário Pinto de Andrade (1929-1990), refutou as asserções lusotropicalistas e referiu que aquela caracterização ignorava a dimensão socioeconómica e política da colonização, "que consiste na pilhagem dos recursos naturais dos países colonizados, na exploração da força de trabalho dos seus habitantes e no desenvolvimento do poder económico, social e político dos colonizadores." (ANDRADE,1978a, s/p; também em ANDRADE, 1974; ANDRADE, 1978b, s/p; in, BRAGANÇA; WALLERSTEIN, 1978, pp.225-233; cit. in, KAJIBANGA, 1999, op. cit., p.3).

Para Victor Kajibanga "a essência social do colonialismo é una”. Daí não acreditar que tenha existido no mundo, colonialismos que se caracterizassem por sentimentos de generosidade e "que supostamente terão investido na formação da nova cultura e do homem novo, em detrimento do saque de recursos naturais (e outras riquezas) e da exploração de mão-de-obra das populações colonizadas." (KAJIBANGA, 1999, p.8).

Esta opinião de Victor Kajibanga vai, também, de encontro à de Frantz Fanon que, na sua obra, "Os Condenados da Terra», afirmava que "as relações colono-colonizado são relações de massa. Ao número o colono opõe a força." (FANON, s/d, p.29). 
Em 1995, o sociólogo francês George Balandier, via a situação colonial em África do seguinte modo:

\begin{abstract}
"A dominação imposta por uma minoria estrangeira, 'racial' e culturalmente diferente, em nome de uma superioridade racial (e ou étnica) e cultural dogmaticamente afirmada, a uma maioria autóctone materialmente inferior; o estabelecimento de relações de maquinismo, de economia poderosa, de ritmo rápido e de origem cristã impõe-se a civilizações sem técnicas complexas, de economia retardada, de ritmo lento e radicalmente 'não cristã'; o carácter antagónico das relações que intervêm entre as duas sociedades, antagonismo que se explica pelo papel de instrumento a que intervêm entre a sociedade dominada; a necessidade para manter a dominação, de recorrer à 'força', mas também a um conjunto de pseudo-justificações de comportamentos estereotipados". (BALANDIER, 1995, s/p; cit. in, ROCHER, 1989, pp.186-187; também em BALANDIER, 1951, pp.44-79; cit. in, KAJIBANGA, 1999, p.9)"11
\end{abstract}

Também o sociólogo angolano José Carlos Venâncio, Professor Catedrático na Universidade da Beira Interior, no seu livro «O facto Africano. Elementos para uma sociologia da África», é peremptório em afirmar que,

“ [...] se a crise do Estado em África é, indubitavelmente, o lado mais visível do subdesenvolvimento observado neste continente, uma boa parte da responsabilidade dessa crise deve ser atribuída ao Estado colonial. A ele se devem as causas estruturais para o subdesenvolvimento generalizado, que ocorre no continente africano e que se prendem com o baixo nível de progresso das sociedades e culturas africanas, após o contacto com os povos europeus; ou seja, 'com o mundo viabilizado pelo colonialismo'." (VENÂNCIO, 2000, p.96).

\title{
Níveis de abordagem e sentido holístico da Educação
}

Podemos encarar as questões educativas a partir de três níveis de abordagem, que, de uma forma sistémica, passo a identifica-las: numa perspectiva macro-sociológica, a educação é concebida como uma questão económica e política, quer pela amplitude de necessidades e recursos envolvidos, quer ainda pelos efeitos globais do seu funcionamento; numa perspectiva meso-sociológica, a educação é entendida como um problema

11 Vitor Kajibanga (1999) informa-nos, que Guy Rocher aponta as seguintes características essenciais da situação colonial: a) a exploração económica estrangeira; b) a dependência política; c) as barreiras sociais e raciais; d) a atomização social; e e) o sistema de justificações. 
organizacional, uma vez que a gestão dos recursos (humanos, materiais e financeiros) tem efeitos imediatos na eficácia e na eficiência do processo educativo; numa perspectiva micro-sociológica, a educação é entendida como um problema psico-social, uma vez que o processo educativo resulta de relações inter-pessoais, estabelecidas entre os diversos protagonistas envolvidos no processo, de entre eles, o professor, hoje com novos desafios, face às rápidas mutações que ocorrem em todo o mundo. (CARMO, 1999, p.251).

Em pleno século XVII, o pedagogo e filósofo morávio Jan Amos Coménius apresentava a sua máxima para o acto educativo - Omnes, Omnia, Omnino - que foi vista, à época, com uma perspectiva holística e revolucionária, ao pretender educar toda a gente com conhecimentos e valores culturais universais, com flexibilidade metodológica e comunicacional, visando um conceito amplo, harmónico e multifacetado de educação para a vida: Todos, tudo, de todas as maneiras. Coménio considerava, que o alargamento e o aprofundamento da educação estavam directamente relacionados com o maior ou menor sentido de humanidade:

\footnotetext{
"Em primeiro lugar, o que se deseja é que assim se consiga educar plenamente para a plenitude humana, não apenas um só homem, ou alguns, ou muitos, mas todos (omnes) e cada um dos homens, jovens e velhos, ricos e pobres, nobres e plebeus, homens e mulheres, numa palavra, todo aquele que nasceu homem para que, enfim, todo o género humano venha a ser educado, seja qual for a sua idade, o seu estado, o seu sexo e a sua nacionalidade. Em segundo lugar, deseja-se que cada homem seja correctamente formado e integralmente educado, não apenas numa coisa, ou em poucas coisas, ou em muitas, mas em todas as coisas (omnia) que aperfeiçoam a natureza humana: conhecer a verdade e não se deixar iludir pelo erro, amar o bem e não se deixar seduzir pelo mal, fazer o que deve fazer e preservar-se do que deve evitar, falar sabiamente acerca de todas as coisas, com todos, quando necessário e nunca se ver obrigado a calar-se; enfim, agir, em todas as circunstâncias, com as coisas, com os homens e com Deus, não levianamente mas prudentemente, e, assim, nunca se afastar do objectivo da sua felicidade. $\mathrm{E}$ que isso seja feito universalmente (omnino). Não para pompa e brilho exterior, mas para a verdade. Ou seja, para tornar todos os homens o mais possível semelhantes à imagem de Deus (segundo a qual foram criados), isto é, verdadeiramente racionais e sábios, verdadeiramente activos e ágeis, verdadeiramente íntegros e honestos, verdadeiramente piedosos e santos e, desse modo, verdadeiramente felizes e bem-aventurados, neste mundo e para toda a eternidade". (COMÉNIO, 1971, in, Enciclopédias Filosóficas; O Enciclopedismo Pansofista Alsted e Coménio, in, www.educ.fc.ul.pt).
} 
Talvez influenciado por Coménius, o sociólogo francês Emile Durkheim (1858-1917), passou a ser um digno representante da perspectiva da cultura do "ser universal", que sustenta um conceito amplo de educação. (CARVALHO - Coord., 2006, pp.198-199). Mas hoje impera uma perspectiva neoliberal, inserida na corrente doutrinária do "ser económico global”, que sobrevaloriza o factor económico em detrimento do social. O neo-liberalismo é definido com sendo a

\begin{abstract}
"hegemonia nas esferas políticas e económica da maior liberdade para as forças de mercado, menor intervenção do Estado, desregulamentação, privatização do património público, preferência relevada pela propriedade privada, abertura para o exterior, ênfase na competitividade internacional e menor compromisso com a protecção social”. (CAEIRO, in, CARMO - Coord., 2001, 218)
\end{abstract}

Tal facto levou o escritor e futurista estadunidense Alvin Toffler (1928-2016) a qualificar o actual momento como o da "teologia do mercado", ${ }^{12}$ onde um sentido restrito de educação se direcciona apenas para o consumo e não para o exercício pleno da cidadania. (TOFFLER, 1998, s/p; in, RELA, 1998, p.36; também MOREIRA, 2003; e MOREIRA, 2002, p.77; cit., in, CARMO, 1977, pp.81-93), Como é sabido, o económico é indissociável do social e do político. Mas, "ao debruçarmo-nos sobre os problemas do desenvolvimento (...) procura-se menos na economia o sentido da totalidade social, do que na totalidade social o sentido da economia”. (TORRES, 1998, pp.41-42 e p.51), já que o mercado deixou de estar ao serviço das pessoas, para as pessoas passassem, de forma altamente consumista, a estarem ao serviço do mercado. Sendo o sentido restrito de educação culturalmente mais fraco,

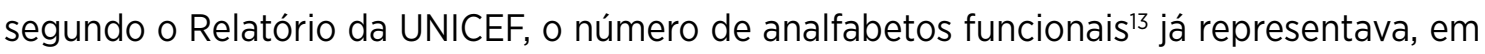
1999, a sexta parte da população mundial. (UNICEF, 1999, p.7; cit. in, CARMO, 2001, p.246).

12 O americano Alvin Toffler lançou em 1980 o «slogan» da «terceira vaga» e dividiu a história humana até à data em três vagas: a primeira que correspondeu à Revolução Agrária, a segunda baseada na Revolução Industrial, e a terceira nascida desde o final da Segunda Guerra Mundial baseada no Conhecimento. "Alvin Toffler é conhecido sobretudo pela sua trilogia sobre a mudança: Choque do Futuro (1970), A 3a Vaga (1981) e Os Novos Poderes (1991). Ainda neste contexto, numa intervenção proferida no Instituto de Defesa Nacional, em Lisboa, Adriano Moreira, na qualidade presidente do Conselho Nacional de Avaliação do Ensino Superior e de Professor Emérito da Universidade Técnica de Lisboa, em vários momentos, utilizou o termo "teologia de mercado", ao referir-se à actual política neo-liberal. Vejamos um dos exemplos: "Talvez um dos triunfos mais dignos de nota da teologia de mercado tenha sido a criação do 'mercado infantil', que tem ao serviço a demagogia publicitária dos meios de comunicação de massa e se transforma numa pressão sistémica sobre a geração de pais responsáveis pela integração social e pela transmissão de valores, de regra ultrapassados na autoridade pela força do mercado".

13 "Cerca de 1000 milhões de pessoas vão entrar no século XXI sem os conhecimentos necessários para ler um livro ou assinar um nome, e muito menos para manejar um computador ou compreender um simples formulário. São analfabetos funcionais do mundo e o seu número é cada vez maior. Apesar da Declaração Universal dos Direitos Humanos, com 50 anos de existência e da Convenção sobre os Direitos da Criança de 1989, cerca de 855 milhões de pessoas - cerca de uma sexta parte da humanidade - serão analfabetos funcionais nas vésperas do novo milénio." Cf. Relatório da UNICEF de 1999. 
Também Frederico Mayor, ex-Director Geral da UNESCO, nos informa que para se vencerem as dificuldades impostas pela mundialização do capitalismo (ou globalização), a promoção de uma qualquer reforma dos conteúdos educativos terá de estar implicitamente direccionada para um emprego ou qualquer outra actividade produtiva. ${ }^{14}$ Todavia, "uma orientação nesse sentido, não implica o descurar da cultura geral, [e] deve imprimir-se a todos os níveis, do primário ao superior." (MAYOR, 1990-1990, pp. 14-15, p.20 e p.25).

Por seu turno, o sociólogo e jornalista galego Ignacio Ramonet, num artigo do Le Monde Diplomatique, refere que a adesão dos países às teses neoliberais parece poder interpretar-se como sendo a substituição de regimes totalitários por regimes "globalitários", em que os dogmas do partido único deram lugar aos "dogmas da globalização e do pensamento único (ao não admitirem nenhuma outra política económica), subordinando, por outro lado, os direitos sociais do cidadão à competitividade e delegando nos mercados financeiros a direç̧ão total das actividades da sociedade dominada". (RAMONET, 1997, s/p; cit., in, SANTOS BENEDITO, 1999, pp.21-22, comunicação não publicada).

\section{Princípios e fins de um amplo conceito de Educação}

A educação, em sentido amplo ou holístico, é um processo de preparação e formação de pessoas (recursos humanos), capazes de, no futuro, participarem, activamente, na vida produtiva, cultural e no exercício pleno da cidadania. Para a obtenção destes fins, a educação não comporta apenas o ensino para a actividade laboral através dos seus diferentes níveis de formação básica, média e/ou superior, mas também o trabalho educativo voltado para o primado da paz, do Estado de Direito democrático, da justiça social e dos direitos humanos. Para tal, correm a aquisição de hábitos, atitudes e valores, que, atendendo ao carácter social da educação, viabilizam "a promoção do desenvolvimento humano da pessoa e a sua integração na sociedade”, mediante dinâmicas da sua própria individualidade, associadas

\footnotetext{
14 O Programa de Acção Especial para África assentava em três pressupostos básicos: "Deveria, estar em sintonia com um outro Programa de Acção das Nações Unidas para a Reconstrução Económica e Desenvolvimento em África adoptado para o período de 1986-1990; Deveria circunscrever-se aos domínios da competência da UNESCO; Não sendo a UNESCO uma agência financiadora, a mesma deveria assegurar-se, juntamente com outros Estados membros, de que haveria uma cooperação, a mais estreita e regular possível, com vista à obtenção de fontes multilaterais e bilaterais de financiamento para o desenvolvimento." O Programa de Acção das Nações Unidas para a Reconstrução Económica e Desenvolvimento em África priorizava o desenvolvimento agrícola pelo homem e para o homem africano. Mas, apesar de todos os esforços, as condições de vida rural em África acabaram por não serem substancialmente diferentes daquelas que já existiam em 1986. Entre os pontos de apoio àquele Programa, que contava também com a participação da UNESCO, encontram-se numerosas acções sob a denominação de "valorização, desenvolvimento, planificação e utilização dos recursos humanos" e acções de luta contra a seca e a desertificação nas suas dimensões científica e tecnológica. Contudo, na vanguarda das acções consideradas como desejáveis, o Programa considerava que se deveriam "modificar radicalmente os sistemas de educação a todos os níveis, para que haja a certeza de que as aptidões, conhecimentos e atitudes, que as necessidades do desenvolvimento impõem, estão criadas." Para além do financiamento, o êxito deste Programa dependeria em muito da forma como a UNESCO estabeleceria uma cooperação efectiva com outras instituições do sistema das Nações Unidas, nomeadamente, com a FAO.
} 
às dinâmicas familiar, escolar, grupal e social, maioritariamente caracterizadas hoje pelo multiculturalismo e pelo plurilinguismo. (LAENG, 1978, p.141).

Juridicamente, a «Declaração Universal dos Direitos Humanos» (10 de Dezembro de 1948), ressalva o direito de todos à Educação e o direito de cada um viver de acordo com a sua própria cultura. Um direito que os Estados de Direito têm a obrigação de observar, mesmo quando se tratem de culturas minoritárias. Um direito que voltou a ser relembrado na Conferência Mundial de Educação para Todos, em 1990, em Jomtien (Tailândia) e no Fórum de Educação para Todos, em 2000, em Dakar (Senegal). Direitos humanos que os países, por falta de vontade política ou por pressão do pagamento do serviço da dívida pública, por vezes, não cumprem. Todavia, se um determinado quadro axiológico ou "conjunto de valores" pode servir de guia para a humanidade e para as suas aspirações de paz, fraternidade e solidariedade, pode também servir de guia para a formação integral ou holística do indivíduo no processo de construção da sua auto-realização e aperfeiçoamento. (TIERNO, 1996, p.11 e p.14; também em LAMA, 2000).

Contudo, também é certo, que "não há apenas ideias opostas ou ideias diferentes a respeito da educação, a sua essência e seus fins. Há interesses económicos, políticos que se projectam também sobre a educação" e que, evidentemente, influenciam e determinam o seu paradigma conceptual e de desenvolvimento. (BRANDÃO, 1986, p.60). Mas, actualmente, face ao carácter unificador de um mundo cada vez mais globalizado, os modelos de desenvolvimento adoptados após a II Guerra Mundial, apesar dos progressos ainda registados, apresentam já os limites de uma concepção de progresso fundada exclusivamente no crescimento quantitativo e material. A Conferência do México, em 1982, através da sua recomendação $n .-27$, ergue a cultura como linha de força e como elemento fundamental da vida de cada indivíduo e de cada comunidade:

\footnotetext{
“(...) Ter em consideração a dimensão cultural nos processos de desenvolvimento e estimular as aptidões criadoras e a vida cultural no seu conjunto, são os dois principais eixos à volta dos quais se articula a Década Mundial do Desenvolvimento Cultural, no intuito de contribuir para a revelação dos grandes desafios mundiais que se apresentam no horizonte do século XXI." (GUIA PRÁTICO DA DÉCADA MUNDIAL DO DESENVOLVIMENTO CULTURAL , 1988-1997,pp.13-14).
}

O assimilacionismo obedece a um processo de aculturação, que conduzà desintegração social e à crise pessoal, já que, do ponto de vista psicossocial, as pessoas podem sentir-se perdidas na mudança, porque, na maior parte das vezes, desaparecem as normas culturais antigas. (NETO, 1993, pp.87-89; também em BIROU, 1882, pp.37-38). Contrariamente às políticas culturais assimilacionistas usadas pelas diferentes administrações coloniais em 
África, a actual corrente do pluralismo cultural, isenta de preocupações hegemónicas, defende um modelo de relacionamento social, em que cada grupo étnico preserva as suas respectivas identidades e partilha, em simultâneo, um conjunto de características culturais com os restantes grupos. (ROCHA-TRINDADE, 1995, p.253).

\footnotetext{
"Fala-se também de assimilação social para definir o processo segundo o qual indivíduos ou grupos, pertencendo a culturas ou a meios diferentes, se transformam em um todo homogéneo. A assimilação dá a ideia de uma absorção por um conjunto sócio-cultural mais forte ou mais vasto de elementos heterogéneos (grupos estranhos ou marginais, imigrantes) que nele entram com a sua cultura, o seu modo de vida, os quais desaparecem ou se integram através desse processo. Robert Jaulin passou recentemente a introduzir a palavra etnocídio "para qualificar a imposição forçada de um processo de aculturação a uma cultura por outra mais poderosa, quando esta conduz à destruição dos valores sociais e morais tradicionais da sociedade dominada, à sua desintegração e depois, ao seu desaparecimento. O etnocídio foi e é ainda frequentemente praticado pelas sociedades de tipo industrial com o objectivo de assimilarem, 'pacificarem' ou transformarem as sociedades ditas 'primitivas' ou 'atrasadas', geralmente a pretexto da moralidade, de um ideal de progresso ou da 'fatalidade evolucionista' (...)".(Cf., JAULIN, 1970 e JAULIN, 1972; in, PANOFF; PERRIN, 1973, p.67).
}

\section{Vertentes de uma educação para a solidariedade e desenvolvi- mento}

Muitos dos conflitos, que, na maior parte das vezes, se sobrepõem aos verdadeiros interesses nacionais, estão associados a questões relacionadas com a identidade étnica, racial, religiosa e político-partidária, quando as sociedades tendem a ser cada vez mais plurais. Para uma educação para o desenvolvimento, Hermano Carmo estabelece áreas transversais e áreas específicas, que abrem espaço para a elaboração de novas grelhas curriculares, capazes de dar resposta adequada aos reais problemas das comunidades em desenvolvimento, mediante um perfil de professores formados no contexto de um quadro axiológico direcionado para o primado da Paz, do Estado de Direito Democrático, dos Direitos Humanos e da Justiça Social.

No campo da transversalidade e face a um mundo em constante mutação, cada cidadão terá que se adaptar à mudança e aprendera geri-la. Deverá aprender a ser autónomo sem ter que se insular no seu individualismo, já que qualquer pessoa vive em comunidade e não de forma isolada. Face à democracia, terá de aprender competências comunicacionais 
indispensáveis ao exercício da mesma, adquirindo as necessárias competências de leitura, de escrita e de conversação (saber falar e saber ouvir). Terá de adquirir competências para o exercício da democracia representativa, aprendendo a escolher, a respeitar as suas escolhas e as dos outros e a utilizar mecanismos democráticos para a substituição dos seus representantes. Terá ainda de adquirir competências para o exercício da democracia participativa (preparar, tomar e executar decisões). Como cidadão, terá de aprender a ser solidário ao nível individual (solidário para com as crianças, adolescentes, adultos e idosos que integram as gerações vivas) e solidário ao nível familiar, organizacional, comunitário, nacional e mundial. Terá ainda que ser solidário no tempo, quer em relação às gerações futuras (sendo solidário para com os netos, como uma forma de garantir o desenvolvimento sustentado), quer em relação às gerações passadas (contribuindo para a defesa do património e assumido a história em todos os seus aspectos positivos e negativos em solidariedade com os seus antepassados).

No campo da especificidade deverá aprender a viver com qualidade, protegendo o ambiente como património comum da humanidade actual e futura. Face à população deverá ser educado para assumir uma paternidade e maternidade responsáveis. Em relação à saúde, deverá ser educado para a nutrição, para a prevenção de doenças e para assumir uma postura favorável à formação sanitária básica. Ao nível da cidadania económica, deverá o cidadão ser educado para a produção, para a gestão de recursos, para a distribuição de bens e serviços e também para o consumo. No âmbito das questões do género, as mulheres deverão ser respeitadas e encaradas com os mesmos direitos e deveres que os homens. Educar uma mulher é o primeiro passo para se educar uma família e, é neste contexto, que as mulheres se tornam em agentes estratégicos de democratização e de desenvolvimento. Face à multiculturalidade, existente em todos os continentes, cada cidadão, através de uma educação intercultural, terá de ser educado para a sua própria identidade cultural, para convivência e coexistência com outras de diferentes culturas e para o ecumenismo. (CARMO, 1999, cit. in, CARMO, 2000, pp.126-127).

\section{A terminar}

Para terminar, rendo a minha singela homenagem à memória da ambientalista queniana Wangari Maathai, Prémio Nobel da Paz, em 2004, primeira mulher africana e décima segunda, ao nível mundial, a alcançar este tão prestigiado reconhecimento. A já falecida Dra Wanghari Maathai foi, com um grupo constituído maioritariamente por mulheres, fundadora do Movimento Cinturão Verde (Green Belt Movement), tendo levado a cabo uma campanha de plantação de árvores, visando deter o desmatamento. Plantaram, em África, cerca de 30 milhões de árvores e conseguiram gerar empregos para as mulheres de diferentes comunidades. Quanto tomou conhecimento da confirmação do Prémio Nobel 
da Paz, em entrevista a uma rádio norueguesa, afirmou o seguinte: "Esta é a maior surpresa de toda a minha vida. Quando plantamos novas árvores, plantamos sementes da paz".

Para além de Mandela, Wangari Maathai, ex-Secretária de Estado do Ambiente da República do Quénia, foi um dos maiores exemplos de solidariedade e respeito pelos direitos humanos, que uma filha de África proporcionou, em prol de um mundo melhor para todos. Com este seu exemplo, ajudou a colocar as questões ambientais na agenda política do seu país, do seu continente e no mundo que é igualmente de todos nós.

O ser humano não tem apenas a faculdade cognitiva que the permite emitir "juízos sobre a realidade". Tem também potencialidades para fazer "juízos de valor sobre as coisas". Ora, são os valores universalmente reconhecidos que configuram a dignidade do homem e da mulher e proporcionam o diálogo universal, ou, mais concretamente, um entendimento generalizado capaz de viabilizar, em contexto democrático, a paz, o respeito pelos direitos humanos e pela justiça social entre todos os povos do mundo. Se um determinado quadro axiológico ou "conjunto de valores" pode servir de guia para a humanidade e para as suas aspirações de paz e fraternidade, também pode servir de guia para a formação holística do indivíduo no processo de construção da sua auto-realização e aperfeiçoamento, através da educação.

\section{Referências bibliográficas}

\section{ALEXANDRE, Valentim., Angola, Origens do Colonialismo Português Moderno (1822-1891).}

Portugal no Século XIX. Antologia de Textos Históricos, texto 1-1, Sá da Costa Editora, Lisboa, 1979.

ALTUNA, Pe. Raul Ruiz de Asúa. Cultura Tradicional Banto. Secretariado Arquidiocesano de Pastoral, Luanda, 1985.

ANDRADE, Mário de. Origens do Nacionalismo Africano, Publicações D. Quixote, Lisboa, 1997. APPIAH, Kwame Anthony. Na casa de meu pai - A África na filosofia da cultura. Contraponto Editora Ltda, Rio de Janeiro, (1997) [1992].

BARBEITOS, Arlindo. Oliveira Martins, Eça de Queirós, a raça e o homem negro; In, SANTOS, Maria Emília Madeira (dir.). A África e a Instalação do Sistema Colonial (c.1885-c.1930), Actas, III Reunião Internacional de História de África, Centro de Estudos de História e Cartografia Antiga, Instituto de Investigação Científica Tropical, Lisboa, 2000

BARBOSA, Jorge Morais. A Língua Portuguesa no Mundo. Junta de Investigação Tropical. Lisboa, 1969

BENDER, Gerald J.. Angola sob o Domínio Português - Mito e Realidade. Sá da Costa Editora. Lisboa, 1976

BRANDÃO, Carlos Rodrigues. O que é a Educação. Editora Brasiliense. São Paulo, 1986 
BIROU, Alain. Dicionário de Ciências Sociais, Publicações Dom Quixote. Lisboa, 1982

CAEIRO, Domingos. Globalização Económica; in, CARMO, Hermano - coord. Problemas Sociais Contemporâneos. Universidade Aberta. Lisboa, 2001

CARMO, Hermano. Ensino Superior a Distância, Universidade Aberta, Temas Educacionais, vol. I. Lisboa, 1997

Desenvolvimento Comunitário. Universidade Aberta. Lisboa, 1999

Hipóteses sobre o Contributo dos Portugueses no Processo de Reabilitação

Pós-Guerra; In, VVAA (2000). Estudos em Memória do Prof. Doutor Luís Sá. Revista Discursos. Universidade Aberta. Lisboa, 2000

(coord.). Problemas Sociais Contemporâneos. Universidade Aberta. Lisboa,

2001

Teoria da Política Social (Um olhar da Ciência Política). Instituto Superior de

Ciências Sociais e Políticas. Lisboa, 2011

CARVALHO, Alberto Dias de (coord.). A cultura humanista. Dicionário da Filosofia da Educação. Porto Editora. Porto, 2006

COLÓNIA DE ANGOLA. Censo Geral da População, Imprensa Nacional. Vol. I. Luanda, 1941

FERRONHA, António Luís. O Tropicalismo Luso ou a Maneira Africana de Estar em Portugal. In, MOREIRA, Adriano; VENÂNCIO, José Carlos. Luso-Tropicalismo. Uma Teoria Social em Questão. Vega e Autores. 1a ed. Lisboa, 2000

FREYRE, Gilberto. Casa Grande e Senzala. Edição “Livros do Brasil”. Lisboa, (1957) [1932]

GALVÃO, Henrique. Angola: Para uma nova política. Fisiologia do Passado, Aspectos do presente. Vol. I. Livraria Popular Francisco Franco. Lisboa, 1937

GONÇALVES, António Custódio. Tradição e Modernidade na (Re)Construção de Angola. Edições Afrontamento. Porto, 2003

GUIA PRÁTICO DA DÉCADA MUNDIAL DO DESENVOLVIMENTO CULTURAL 1988 - 1997. Resolução 41/187 adoptada em 8 de Dezembro de 1986 pela Assembleia-geral das Nações Unidas. UNESCO. Paris, 1988

JEWSIEWICKI, Bogumil. In, MUNDIMBE, V.Y. The Invention of Africa - Gnosis, Philosophy, and the Order of Knowledge, Indiana University Press - Blooming and Indianapolis. James Currey. London, 1988

KAJIBANGA, Víctor. Crise da Racionalidade Lusotropicalista e do "Paradigma" da Crioulidade. 0 caso da antropossociologia de Angola. Comunicação apresentada ao Colóquio "O Luso-tropicalismo Revisado" realizado em Lisboa, na Sociedade de Geografia de Lisboa, de 11 a 12 de Fevereiro de 1999. 
A Alma Sociológica na Ensaística de Mário Pinto de Andrade. Instituto Nacional das Industrias Culturais. Luanda, 2000

LAENG, Mauro. Dicionário de Pedagogia. Publicações Dom Quixote. Lisboa, 1978

LAMA, Dalai. Ética para o Novo Milénio. Círculo dos Leitores, Lisboa, 2000

LEMOS, Alberto de. Bases para a Solução dos Problemas da Colonização de Angola. Edição do autor. Lisboa, 1941

- M’BOKOLO, Elikia. Prefácio. Accra, 17 de Junho de 2001. In, GONÇALVES, António Custódio.

Tradição e Modernidade na (Re)Construção de Angola. Edições Afrontamento. Porto, 2003

MAYOR, Frederico. África - Uma Prioridade. Programa de Acção Proposto pelo Director-Geral; Centro Unesco do Porto, Departamento da Fundação Eng. António de Almeida, Porto, 1990-1995

MARTINS; Oliveira. 0 Brasil e as Colónias Portuguesas. Guimarães \& C. ํㅡㄹ Editores. 7ำ ed. Lisboa, (1920), [1978]

MAZULA, Brazão. Educação, Cultura e Ideologia em Moçambique: 1975-1985. Fundo Bibliográfico de Língua Portuguesa \& Edições Afrontamento. Lisboa, 1995

MEDINA, João; HENRIQUES, Isabel Castro. A Rota dos Escravos: Angola e a rede do comércio negreiro. Cegia. Lisboa, 1996

MEMMI, Albert. O Racismo. Editorial Caminho. Lisboa, 1993

MOREIRA, Adriano. Administração da Justiça aos Indígenas. Agência-Geral do Ultramar. Lisboa, 1955 The 'Elites' of the Portuguese 'Tribal' Provinces (Guinea, Angola,

Mozambique, International Social Science Bulletin, 1956

Os Trópicos da Europa. Academia Internacional de Cultura Portuguesa -

AICP. Boletim nำ29. Lisboa, 2002

Intervenção, Seminário sobre Educação da Juventude: Conceito de

Liderança e Cidadania. Instituto de Defesa Nacional. Lisboa, 7 de Outubro de 2003

MOREIRA, Adriano; VENÂNCIO, José Carlos (Org.). Luso-tropicalismo: Uma teoria social em

questão. Vega Editora. Lisboa, 2000

MUNDIMBE, V.Y. The Invention of Africa - Gnosis, Philosophy, and the Order of Knowledge. Indiana University Press - Blooming and Indianapolis. James Currey. London, 1988

NETO, Felix. Psicologia da Migração Portuguesa. Universidade Aberta, Lisboa, 1993

PANOFF, Michel; PERRIN, Michel. Dicionário de Etnologia. Edições 70, Lisboa, 1973

PÉLISSIER, René. História das Campanhas de Angola. Editorial Estampa. vol. I. Lisboa, 1986

PROVÍNCIA DE ANGOLA. II Recenseamento Geral da População 1950. Direcção dos Serviços de Estatísticas. Vol. I. Imprensa Nacional. Luanda, 1953

CONHECER: DEBATE ENTRE O PÚBLICO E O PRIVADO. V. 11 № 26/2021.1 
RELA, José Manuel Zenha. África Século XXI. Os Desafios da Globalização e as Respostas do Desenvolvimento. Sociedade de Geografia de Lisboa. Lisboa, 1998

ROCHA-TRINDADE, Maria Beatriz. Sociologia das Migrações. Universidade Aberta. Lisboa, 1995

SANTOS BENEDITO, A globalização e os Desafios à Educação. Coimbra. (comunicação não publicada), 1999

SOUSA FERREIRA, Eduardo de. Aspectos do Colonialismo Português. Seara Nova. Lisboa, 1974 TINHORÃO, José Ramos. Os Negros em Portugal. Uma presença silenciosa. Coleç̧ão Universitária. Editorial Caminho S.A. 2ª ed. Lisboa, (1997) [1988]

TIERNO, Bernabe. Valores Humanos. Taller de Editores, S. A. Madrid, 1996

TORRES, Adelino. Horizontes do Desenvolvimento Africano no Limiar do Século XXI. Veja. Lisboa, 1998

UNITED NATIONS, Report of the Sub- Committee on the Situation in Angola (A/4978), 1962

VENÂNCIO, José Carlos. O facto Africano. Elementos para uma sociologia da África. Veja. Lisboa, 2000

WOHLGEMUTH, Patrícia. The Portugueses Territories and the United Nations, Carnegie

Endowment for International Peace. New York, 1963

ZAU, Filipe. Educação em Angola; Novos Trilhos para o Desenvolvimento. Movilivros, Luanda, 2009

\section{SUPORTES DA INTERNET}

O Enciclopedismo Pansofista Alsted e Coménio. Enciclopédias Filosóficas. Disponível em: http:// www.educ.fc.ul.pt/hyper/enciclopedia/cap3p3/pansofista.htm. Acessado em: 23 de out. 2020

Frazão, Dilva. Nelson Mandela: político sul-africano. E Bibiografia. Disponível em:

https://www.ebiografia.com/nelson_mandela/. Acessado em: 30 de out. 2019

Nelson Mandela: Ninguém nasce odiando outra pessoa pela. Pensador. Disponível em:

https://www.pensador.com/frase/MzYONzkx/. Acessado em: 26 de out. 2020

Eusébio de Queirós. Wikipédia. Disponível em: https://pt.wikipedia.org/wiki/Eus\%C3\%A9bio_de_ Queir\%C3\%B3s. Acessado em: 12 de out. 2020

Silva, C. M. A. Ecmnésia Histórica Colonial. Portugal em Linha. Disponível em:

http://www.portugal-linha.pt/opiniao/CAlexandrino/cron5II.html. Acessado em: 11 de maio. 2020 


\section{Para citar este artigo}

Norma A - ABNT

ZAU, F. S. P. Os direitos humanos como primado de um sentido holístico de educação para o desenvolvimento em contexto de multiculturalidade. Conhecer: Debate entre o Público e o Privado, v. 11, n. 26, p. 132-161, 2021.

\section{Norma B - APA}

Zau, F. S. P. (2021). Os direitos humanos como primado de um sentido holístico de educação para o desenvolvimento em contexto de multiculturalidade. Conhecer: Debate entre o Público e o Privado, 11(26), 132-161.

\section{Norma C - Vancouver}

Zau FSP. Os direitos humanos como primado de um sentido holístico de educação para o desenvolvimento em contexto de multiculturalidade. Conhecer: Debate entre o Público e o Privado [Internet]. 2021 [cited Mar 4, 2021];11(26):132-161. Available from: https://revistas.uece.br/index.php/ revistaconhecer/article/view/4649 